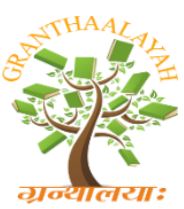

INTERNATIONAL JOURNAL OF RESEARCH GRANTHAALAYAH A knowledge Repository

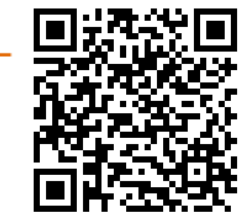

Science

\title{
STUDIES ON ANTIMICROBIAL ACTIVITY, PHYTOCHEMICAL SCREENING TESTS, BIOCHEMICAL EVALUATION OF CLITOREA TERNATEA LINN. PLANT EXTRACTS
}

\author{
Sriyeta Chakraborty ${ }^{1}$, Souvagyalaxmi Sahoo ${ }^{* 1}$, Anjana Bhagat ${ }^{2}$, Sangita Dixit $^{2}$ \\ ${ }^{1,2}$ Department of Biotechnology, Tectona Biotech Resource Centre, \\ Bhubaneswar-751002, Odisha, India
}

\begin{abstract}
The Clitoria ternatea medicinal plant deserves multipotent bioactive secondary metabolites potentials in a great deal. The aim of this study is to analyze the phytochemical, biochemical and antimicrobial activities of the different plant extracts. Extracts from the leaves and seed of Clitoria ternatea were extracted with water and methanol. Phytochemical analysis observed the presence of flavonoids, Carbohydrates, phenols, saponins, tannins, quinines, terpenoids and oxalate components in leaves and seed extract of methanol. In seeds aqueous and methanol extracts, alkaloids, carbohydrates, glycosides, flavonoids, tannins, saponins, amino acids, proteins, terpenoids were present. Quantitatively, seed and leaves methanol extract have good quantity of phenol, carbohydrates, tannin, flavonoid and terpenoid. Two bacterial and fungal strains were taken for antimicrobial analysis. The antibacterial study against E.coli and B.subtlis, result in the zone of inhibition which was more in case of methanol extracts. In antifungal analysis, the extracts were showed equally effective against A.niger whereas the seeds methanol extracts were little more effective against in case of P.chrysogenum. Hence, C. ternatea can be used to discover bioactive natural products that may serve as a base in the development of new natural plant-based medicine.
\end{abstract}

Keywords: Clitoria Ternatea; Quantitative; Antibacterial; Antifungal; Secondary Metabolites.

Cite This Article: Sriyeta Chakraborty, Souvagyalaxmi Sahoo, Anjana Bhagat, and Sangita Dixit. (2017). "STUDIES ON ANTIMICROBIAL ACTIVITY, PHYTOCHEMICAL SCREENING TESTS, BIOCHEMICAL EVALUATION OF CLITOREA TERNATEA LINN. PLANT EXTRACTS." International Journal of Research - Granthaalayah, 5(10), 197-208. https://doi.org/10.29121/granthaalayah.v5.i10.2017.2296.

\section{Introduction}

Clitoria ternatea Linn. Is an appealing perennial climber with conspicuous blue or white flower. It is commonly known as "Aparajita", "butterfly pea", "shankhapuspi" and belongs to the Fabaceae family. It is traditionally used to deal with diverse illnesses (1). The plant is native to south-east Asia and allotted in tropical Asia including India, the Philippines and Madagascar. 
Seeds 6-10 easy yellowish brown. Useful elements are roots, leaves and seeds. Clitoria ternatea has diuretic and laxative effects. Seeds are used in belly cramps, sell mind and the leaves and flowers have the cooling effects (2). This whole plant extract has potential medicinal values such as anti-helmintic (3), anti-inflammatory, antipyretic, antibacterial (4), analgesic (5), antidepressant, anxiolytic, sedative, anticonvulsant, anticancer, hypoglycemic, properties $(6,7)$. In conventional Ayurvedic medication, it's been used for hundreds of years as a memory enhancer, nootropic, antistress, anxiolytic, antidepressant, anticonvulsant and sedative agent. The active constituents include resin, tannins, taraxerone and starch and taraxerol (8). The plant includes numerous secondary metabolites consisting of kaempferol and its glucoside-clitorin, taraxerol and a lactone aparajitin (9). Seeds contain - hexacosanal, Sistosterol, and anthoxanthin (10). The present study deals with the Quantitative and qualitativ analysis of leaf and seed of Clitoria ternatea for the presence of Alkaloids, Tannins, Glycosides, Steroids, Saponins, Flavonoids and Phenols.

Clitoria ternatea belong to the Fabaceae family and activities studies show that Clitoria ternatea display potent antimicrobial activity against $E$. coli, $K$. pneumonia, $P$. aeruginosa. These peptides may have potential to be developed as antimicrobial and anti-cancer agents. In animal tests the methanolic extracts of C. ternatea demonstrated anxiolytic, antidepressant, anticonvulsant and antistress activity (11). The active constituents include tannins, resins, starch, taraxerol, and taraxerone. This work attempts to find out the anti microbial properties of Clitoria ternatea, against select list of microbes and extraction, isolation and characterization of compounds that give these properties to these plants.

\section{Materials and Methods}

\subsection{Selection and Procurement of Plants}

Healthy and disease free leaves and seeds of Clitoria ternatea were collected from the greenhouse nursery of Tectona Biotech Resource Center, Bhubaneswar, Odisha. Among the two varieties, white and blue variety flowering plant, the blue variety flowering plants leaves and seeds were taken for further studies.

\subsection{Preparation of Extracts}

The collected Mature, healthy and fresh leaves and seeds (all seed coats were evacuated) of $C$. ternatea were washed in tap water for ten minutes and rinsed with sterile distilled water and completely air dried. The dried leaves and seeds were grinded into fine powder. For methanol and aqueous extracts, $10 \mathrm{~g}$ of two powder sample was dissolved in $100 \mathrm{ml}$ of distilled water and $60 \%$ methanol solution. The flasks were kept in room temperature in rotary shaker at $100 \mathrm{rpm}$ for $72 \mathrm{hrs}$. Then this extracts were filtered separately by using Whatman No.1 filter paper and stored refrigerator at $4^{\circ} \mathrm{C}$. 


\subsection{Phytochemical Qualitative Screening}

The samples were screened for alkaloids, carbohydrates, glycosides, flavonoids, phenols, tannins, amino acids, proteins, saponins, sterols, terpenoids, quinones, oxalate which helps to confirm the presence of the secondary metabolites in the prepared extracts.

Test for alkaloids: Wagner's Test: About $0.5 \mathrm{ml}$ of plant sample was treated with Four to five drops of Wagner's reagent ( $2 \mathrm{~g}$ of potassium iodide and $1.27 \mathrm{~g}$ of iodine taken in $100 \mathrm{ml}$ of water) and formation of reddish brown precipitate (or coloration) was observed.

Test for Carbohydrates (Molisch's test): Four to five drops of Molisch's reagent (dissolve 3.75 gram of 1- $\alpha$ naphthol was dissolved in $25 \mathrm{ml}$ of $99 \%$ Ethanol) were added to $2 \mathrm{ml}$ of extracts. Then $2 \mathrm{ml}$ of conc. $\mathrm{H}_{2} \mathrm{SO}_{4}$ was added down the side of the test tube. Then this mixture sample was allowed to stand for 2-3 mins. Formation of a red or dull violet colour at the interphase of the two layers was a positive test.

Test for Glycosides (Keller Kelliani's test): About 5ml of plant sample and $2 \mathrm{ml}$ of glacial acetic acid was taken in a test tube and then one drop of ferric chloride solution was added to it. This was carefully under layer with $1 \mathrm{ml}$ concentrated sulphuric acid. A brown ring at the interface indicated the presence of Glycosides.

Test for Flavonoids (Alkaline reagent test): $2 \mathrm{ml}$ of extracts was treated with few drops of $20 \%$ sodium hydroxide solution. Formation of intense yellow colour, that becomes colourless on addition of dilute hydrochloric acid, indicates the presence of flavonoids.

Test for Phenols (Ferric chloride test): A fraction of the extracts was treated with aqueous 5\% ferric chloride and observed for formation of deep blue or black colour.

Test for tannins (Precipitate test): Deposition of a red precipitate when $2 \mathrm{ml}$ of extract was boiled with $1 \mathrm{ml}$ of $1 \%$ aqueous hydrochloric acid was taken as evidence for the presence of tannins.

Test for Amino acids and Proteins (Ninhydrin test): $2 \mathrm{ml}$ of filtrate was treated with 2-5 drops of ninhydrin solution ( $1 \%$ ninhydrin solution in acetone) placed in a boiling water bath for 1-2 minutes and observed for the formation of purple color.

Test for Saponins (Foam test): To $2 \mathrm{ml}$ of plant extract was treated with $6 \mathrm{ml}$ of water in a test tube. The mixture was shaken vigorously and observed for the formation of persistent foam for 5 mins that confirms the presence of saponins.

Test for Sterols (Liebermann-Burchard test): $1 \mathrm{ml}$ of extract was treated with drops of chloroform, acetic anhydride and conc. sulphuric acid and examined for the colour change in red or dark pink. 
Test for Terpenoids (Salkowki's test): $1 \mathrm{ml}$ of chloroform was added to $2 \mathrm{ml}$ of each extract followed by a few drops of concentrated sulphuric acid and observed immediately formation of a reddish brown precipitate which indicated presence of terpenoids.

Test for Quinones: A small amount of extract was treated with concentrated $\mathrm{HCl}$ and observed for the formation of yellow precipitate (or coloration).

Test for Oxalate: To $3 \mathrm{ml}$ of extracts a few drops of glacial acetic acid were added. A greenish black coloration indicates presence of oxalates.

Test for Resins: To $3 \mathrm{ml}$ extracts $5 \mathrm{ml}$ of $\mathrm{H}_{2} \mathrm{O}$ was added and mixed. Presence of turbidity indicates the resin is present in the plant extract.

\section{Phytochemical Quantitative Screening}

\subsection{Determination of Total Phenol Content}

The total phenol content was determined by the procedure of Skerget et al. 2005. In brief, different conc. of the plant extracts were treated to $0.1 \mathrm{ml}$ of F.C. reagent and $2.5 \mathrm{ml}$ of $0.2 \mathrm{~N}$ $\mathrm{Na} 2 \mathrm{CO} 3$ were added and incubated for $30 \mathrm{~min}$ at room temperature. Absorbance was taken using $\mathrm{UV}$-spectrophotometer at $760 \mathrm{~nm}$. Gallic acid became used have been expressed as $\mu \mathrm{g}$ of gallic acid equivalents according to gram dry mass of extract ( $\mu \mathrm{g} \mathrm{GAE} / \mathrm{gDM})$.

\subsection{Determination of Total Flavonoid Content}

The total flavonoid content was determined by the aluminium chloride calorimetric assay. $0.3 \mathrm{ml}$ of plant extracts was mixed with $0.15 \mathrm{ml}$ of $\mathrm{AlCl} 3.6 \mathrm{H} 2 \mathrm{O}(0.3 \mathrm{M}), 0.15 \mathrm{ml}$ of $\mathrm{NaNO} 2(0.5 \mathrm{M})$, and $3.4 \mathrm{ml}$ of $30 \%$ methanol in a test tube, After $5 \mathrm{~min}, 1 \mathrm{ml}$ of $\mathrm{NaOH}$ was added. Then the O.D. was measure at $506 \mathrm{~nm}$. Rutin was used as a standard solution of flavonoid. The total flavonoid content was examined with the rutin equivalents consistent with $g$ of dried fraction.

\subsection{Determination of Total Carbohydrate by Anthrone Method}

$100 \mathrm{mg}$ of the sample was weighed into a boiling tube. Then the sample was hydrolyzed by putting in a boiling water bath for 3 hours with five $\mathrm{ml}$ of $2.5 \mathrm{~N}$ hydrochloric acid then cooled to room temperature. Neutralized it with solid $\mathrm{Na}_{2} \mathrm{Co}_{3}$ until the effervescence ceases. The volume was made up to $100 \mathrm{ml}$ and centrifuge at $10,000 \mathrm{rpm}$ for 20 mins. Then the 0.5 and $1 \mathrm{ml}$ aliquots were taken for further analysis. The standard was prepared by $0,0.2,0.4,0.6,0.8$ and $1 \mathrm{ml}$ of the sucrose. The volume was made up to $1 \mathrm{ml}$ in all the tubes by adding distilled water. Then $4 \mathrm{ml}$ of anthrone reagent was added (Dissolve $200 \mathrm{mg}$ anthrone in $100 \mathrm{ml}$ of ice-cold $95 \% \mathrm{H}_{2} \mathrm{SO}_{4}$. Prepare fresh before use.). Then the mixture was heated for 8 minutes by using boiling water bath. Cooled rapidly and read the green to dark green color at $630 \mathrm{~nm}$. 


\subsection{Estimation of tannins}

Estimation of tannins was carried out by using Folin-Denis reagent. Folin-Denis reagent (5 ml) was added to an aliquot $(1 \mathrm{ml})$ of the 1: 100 weakening depicted previously. The solution was shaken vigorously and permitted to remain for three minutes. Sodium carbonate solution (10 ml) was added and the sample again was shaken and permitted to remain for two hours. Around then, the sample was centrifuged until the particulate materials have been evacuated. The absorbance was measured at $700 \mathrm{~nm}$ by UV/VIS Spectrophotometer (Perkin-Elmer 551). A blank was also analyzed in every sample. By a series of dilutions of the tannin solutions prepared (1: 250, 1: 50, 1: $40,1: 25$, and 1: 10), a standard curve was plotted for tannic acid.

\subsection{Estimation of Terpenoids}

To $1 \mathrm{ml}$ of plant extract was treated with $3 \mathrm{ml}$ of chloroform. The sample mixture was thoroughly vortexed and left for 3 mins. Then 200ul of conc. $\mathrm{H}_{2} \mathrm{SO}_{4}$ was added and mixture was incubated for 1.5-2 hrs in dark condition and during incubation a reddish brown precipitation was formed. Then carefully and gently all the supernatant of the reaction mixture was decanted without disturbing the precipitation. $3 \mathrm{ml}$ of $95 \%(\mathrm{v} / \mathrm{v})$ methanol was added and vortexed thoroughly until all the precipitation dissolve in methanol completely. The absorbance was reading was taken at $538 \mathrm{~nm}$ using UV visible spectrophotometer. The total terpenoid content was calculated was calibration curve of linalool and the results were expressed as linolool equivalent $(\mathrm{mg} / \mathrm{g})$.

\subsection{Antimicrobial Activity of Leaf and Seed Extracts of Clitoria Ternatea}

Pure bacterial and fungal cultures were obtained from the Tectona Biotech Resource Center, Bhubaneswar. Two bacterial culture Escherichia coli, Bacillus subtilis, were maintained in nutrient agar slants at $4^{\circ} \mathrm{C}$ and were subculture into newly prepared nutrient agar slants, every two-week. Two fungal cultures of Penicillium chrysogenum, Aspergillus niger were maintained in Potato dextrose agar (PDA) medium. Antimicrobial activity was determined using the standard disc diffusion method. The crude methanol extracts were used for bioassay against both bacteria and fungi. Sterile discs having six mm diameter prepared from Whatmann No.1 filter paper were loaded with $100,200,400 \mu \mathrm{g} / \mathrm{ml}$ of gel methanol and aqueous extracts and introduced into the sterile Muller - Hinton agar medium for bacterial and PDA medium for fungal test organisms. The plates were incubated 24 hours at $37^{\circ} \mathrm{C}$ for bacteria and 48 hours at $28^{\circ} \mathrm{C}$ for fungus. By measuring the diameter of zone of inhibition $(\mathrm{mm})$ produced after incubation the antimicrobial activity was examined.

\section{Results and Discussions}

\subsection{Qualitative Phytochemical Analysis}

Phytochemical screening of medicinal plants is important for identification of new sources of therapeutical medicine and industrial importance (12). In the present analysis, the methanolic leaf extract of $C$. ternatea observed the presence of various phytochemicals such as proteins, carbohydrates, glycoside, resins, alkaloid, steroid, tannin, and phenols. The presences of steroidal 
compounds are important and interest in pharmacy because of their relationship with compounds as sex hormones (Okwu et al., 2001).

Phytochemical analysis of Clitoria ternatea leaves and seeds were carried out in aqueous and methanol extract respectively using different methods and the results were shown below in the Table 1. In our result, the leaves aqueous extract showed positive result against alkaloids, carbohydrates, flavonoids, phenols, tannins, saponins, terpenoids, quinones components whereas components like glycosides, aminoacids, proteins, resins and oxalate were absent. Alkaloids are produced by large variety of organisms including bacteria, fungi, plants and animals and many alkaloids are toxic to some organisms while some have bitter taste (14) it was attributed that tannins contributed the property of astringency leading to faster healing of wounds and inflamed mucous membranes (13). Terahara et al. (15), Uma (16) and Manalisha, and Chandra (17) reported the presence of Tannins and Resins in the roots, we found that they are absent in roots. Carbohydrates, flavonoids, phenols, tannins, saponins, terpenoids, quinines and oxalate components were present in leaves methanol. In the case of seeds extracts, alkaloids, carbohydrates, glycosides, flavonoids, tannins, saponins, amino acids, proteins, terpenoids were present in aqueous extract. Except oxalate all the other components were present in the methanol seeds extract. Resins was absent in all the extracts.

Table 1: Qualitative phytochemical analysis for different secondary metabolites in the leaves and seeds extracts of Clitorea ternatea

\begin{tabular}{|c|c|c|c|c|}
\hline $\begin{array}{c}\text { Secondary } \\
\text { Metabolites }\end{array}$ & $\begin{array}{c}\text { Leaves aqueous } \\
\text { extract }\end{array}$ & $\begin{array}{c}\text { Leaves methanol } \\
\text { extract }\end{array}$ & $\begin{array}{c}\text { Seeds aqueous } \\
\text { extract }\end{array}$ & $\begin{array}{c}\text { Seeds methanol } \\
\text { extract }\end{array}$ \\
\hline Alkaloids & ++ & - & + & ++ \\
\hline Carbohydrates & ++ & +++ & +++ & ++ \\
\hline Glycosides & - & - & +++ & + \\
\hline Flavonoids & +++ & + & +++ & ++ \\
\hline Phenols & ++ & ++ & - & +++ \\
\hline Tannins & ++ & ++ & ++ & ++ \\
\hline $\begin{array}{c}\text { Amino acids and } \\
\text { proteins }\end{array}$ & - & - & +++ & ++ \\
\hline Saponins & ++ & ++ & + & +++ \\
\hline Terpenoids & + & + & - & + \\
\hline Quinones & ++ & ++ & - & - \\
\hline Oxalate & - & + & - & - \\
\hline Resins & - & - & & \\
\hline
\end{tabular}

\subsection{Quantitative Phytochemical Analysis}

\subsubsection{Estimation of Phenol}

The results of total phenol content in the examined plant extract using the Folins Ciocalteu's method using Gallic acid to plot the standard curve (graph: 1 ). These were expressed in terms of Gallic acid equivalent (the standard curve equation: $y=0.0102 x ; R^{2}=0.9494$ ). The results of total phenol content of Clitoria ternatea extract is showing in Table 2. Our results with methanolic leaf and seed extract in Clitoria ternatea extract showed a significant increase in phenol content $(\# \mathrm{P}<0.001)$. Total phenol content in Clitoria ternatea leaf and seed was 67.25 
$\mu \mathrm{g} / \mathrm{mL}$ and $79.70 \mu \mathrm{g} / \mathrm{mL}$. Our results indicated higher total phenol content in methanolic extract of Clitoria ternatea plant compare to aqueous extract.

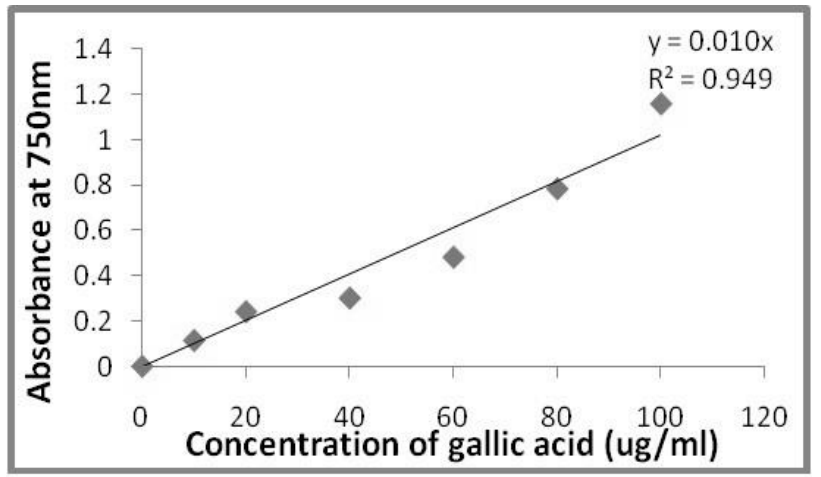

Graph 1: Standard curve for Gallic acid

Table 2: Estimated Phenol content present in the extracts of Clitoria ternatea

\begin{tabular}{|l|c|}
\hline \multicolumn{1}{|c|}{ Extracts } & $\begin{array}{c}\text { Total phenolic content } \\
\text { (mg of GAE/100 g of dry mass). }\end{array}$ \\
\hline Leaves Aqueous (S1) & 54.01960784 \\
\hline Leaves methanol (S2) & 67.25490196 \\
\hline Seed aqueous (S3) & 45.39215686 \\
\hline Seed methanol (S4) & 79.70588235 \\
\hline
\end{tabular}

\subsubsection{Estimation of Flavonoid}

The total flavonoid contents in the examined different plant extract using the Aluminium Chloride Colorimetric Assay were expressed in terms of Quercetin equivalent (the standard curve equation: $\left.\mathrm{y}=0.0007 \mathrm{x} ; \mathrm{R}^{2}=0.916\right)$. The results of total flavonoid contents of Clitoria ternatea leaf and seed extract is showing in Table 3. Quercetin was used to plot the standard curve (graph 2). The values obtained for the concentration of total flavonoid were expressed as $\mathrm{mg}$ of quercetin equivalents/100 $\mathrm{g}$ of dry mass .In this case leaves methanol extract have a high content of flavonoid.

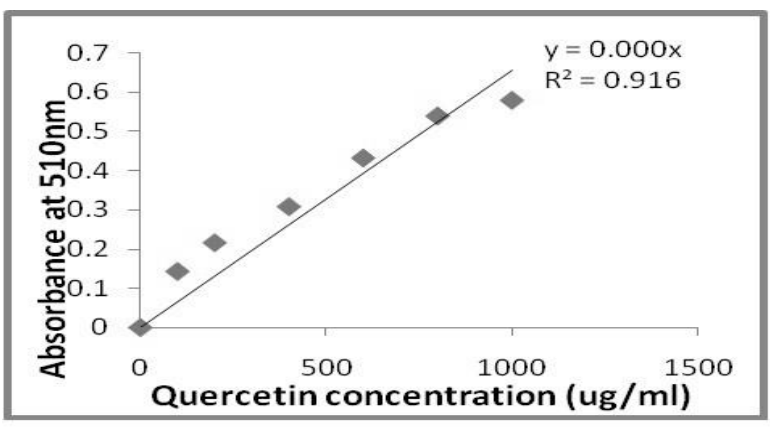

Graph 2: Standard curve for Quercetin 
Table 3: Estimated flavonoid content present in the extracts of Clitoria ternatea

\begin{tabular}{|c|c|}
\hline Extracts & $\begin{array}{c}\text { Total flavonoid content } \\
\text { (mg of Quercetin /100 g of dry mass). }\end{array}$ \\
\hline Leaves Aqueous (S1) & 147.1428571 \\
\hline Leaves methanol (S2) & 271.4285714 \\
\hline Seed aqueous (S3) & 85.71428571 \\
\hline Seed methanol (S4) & 5.571428571 \\
\hline
\end{tabular}

\subsubsection{Estimation of Carbohydrate}

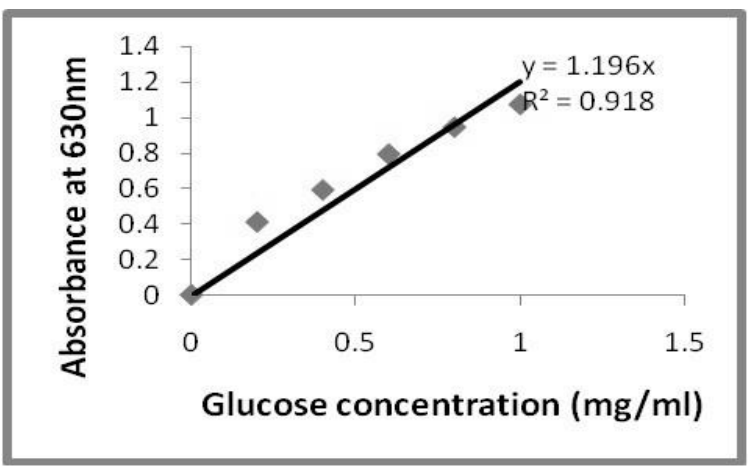

Graph 3: Standard curve for Glucose

The total carbohydrate content in the different plant extract using the Anthrone method were expressed in terms of glucose equivalent (the standard curve equation : $\mathrm{y}=1.1966 \mathrm{x} ; \mathrm{R}^{2}=$ 0.9181) (graph. 3). The values obtained for the concentration of total glucose were expressed as mg of glucose equivalents/100 mg of dry mass. The total carbohydrates contents in the examined extracts were tabulated in Table 4 where all the extracts almost have a same amount of carbohydrates but as calculated seed methanol showed (78.22) a high content.

Table 4: Estimated carbohydrates content present in the extracts of Clitoria ternatea

\begin{tabular}{|c|c|}
\hline Extracts & $\begin{array}{c}\text { Total glucose content } \\
\text { (mg /100 mg of sample) }\end{array}$ \\
\hline Leaves Aqueous (S1) & 77.6784222 \\
\hline Leaves methanol(S2) & 76.96807622 \\
\hline Seed aqueous (S3) & 77.05164633 \\
\hline Seed methanol(S4) & 78.22162795 \\
\hline
\end{tabular}

\subsubsection{Estimation of Tannins}

The total tannin content in the different plant extract using the Folin-Denis reagent method were expressed in terms of tannic acid equivalent (the standard curve equation : $\mathrm{y}=0.3247 \mathrm{x} ; \mathrm{R}^{2}=$ 0.9678) (graph. 4). The values obtained for the concentration of total tannic acid were expressed as $\mathrm{mg} / \mathrm{m}$. The total tannin contents in the examined extracts were tabulated in Table 5. The content of tannin was observed low in all the extracts. 
Table 5: Estimated tannin content present in the extracts of Clitoria ternatea.

\begin{tabular}{|l|l|}
\hline \multicolumn{1}{|c|}{ Extracts } & $\begin{array}{c}\text { Total Tannin content } \\
(\mathbf{m g} / \mathbf{m l})\end{array}$ \\
\hline Leaves Aqueous (S1) & 0.210348014 \\
\hline Leaves methanol (S2) & 0.201108716 \\
\hline Seed aqueous (S3) & 0.225746843 \\
\hline Seed methanol (S4) & 0.208192177 \\
\hline
\end{tabular}

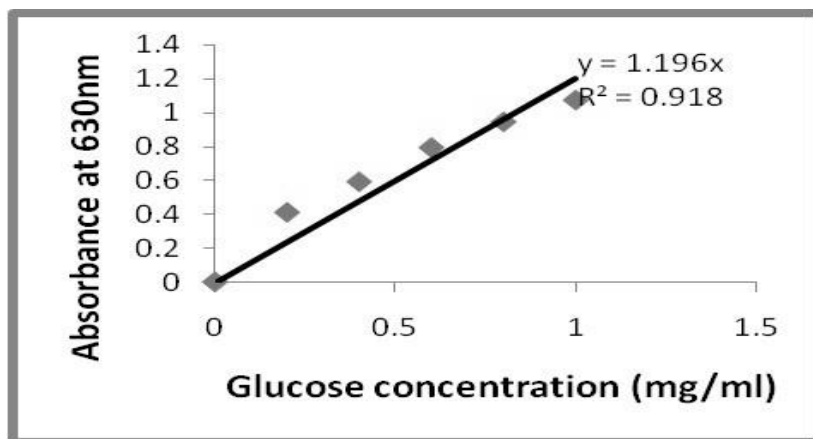

Graph 4: Standard curve for Tannic acid

\subsubsection{Estimation of Terpenoids}

Total terpenoid content in the different plant extract using the linalool standard curve were expressed in terms of linalool equivalent (the standard curve equation: $y=0.0143 x ; R^{2}=0.9801$ ) showing in graph.5. The values obtained for the concentration of total terpenoids were expressed as $\mathrm{mg} / 100 \mathrm{~g}$. The total terpenoid contents of plant extracts were tabulated in Table 6 . In this experiment, aqueous extracts of both the leaf and the seed have a much higher content of terpenoid than the methanol extracts.

Table 6: Estimated Terpenoid content present in the extracts of Clitoria ternatea

\begin{tabular}{|c|c|}
\hline Extracts & $\begin{array}{c}\text { Total terpenoid content } \\
\text { (mg /g) }\end{array}$ \\
\hline Leaves Aqueous (S1) & 5.06993007 \\
\hline Leaves methanol (S2) & 0.895104895 \\
\hline Seed aqueous (S3) & 5.972027972 \\
\hline Seed methanol (S4) & 0.674825175 \\
\hline
\end{tabular}

\subsubsection{Antimicrobial Analysis}

The results of the antimicrobial screening assay of the extracts of all parts of C. ternatea are shown in table 8 and 9. The leaf and seed of plant included in the present study were found to be active on at least one of the selected microbial strains tested. In general, among the tested microbial strains, bacteria were found to be more sensitive to the test extracts than fungi. The preliminary disk diffusion assay of methanol C. ternatea extracts against microbes showed that the leaf and seed extracts were more favourably compared to the rest of the extracts. Methanol seed extract $(0.4 \mathrm{ml})$ having good zone of inhibition against subtilis and E.coli. Was observed in Table 7 compare to all other. From table 8, antifungal activities of Clitoria 
ternatea was to be found less effective to the positive controls. The different extract of Clitoria ternatea in different concentration showed different spectrum of activities, especially by the disk diffusion method where the microorganisms tested produced difference zones of inhibition. It was observed that, the extracts of difference parts of Clitoria ternatea have different efficacy against the selected microorganisms. These differences could be due to the nature and level of the antimicrobial agents present in the extracts and their mode of action on the different test microorganisms (18). Haripriya et.al. (19) Observed that petroleum ether extracts of S. involvens showed higher antibacterial activity against E. coli and Pseudomonas. Similarly in the present study also, Methanol extracts of leaf and seed showed the maximum zone of activity against all bacteria and fungus pathogen.

Table 7: Formation of zone of inhibition against some selected bacteria

\begin{tabular}{|c|c|c|c|c|c|c|c|c|}
\hline \multirow{2}{*}{$\begin{array}{c}\text { Concentration } \\
\text { of } \begin{array}{c}\text { extracts } \\
(\mathbf{m l})\end{array}\end{array}$} & \multicolumn{9}{|c|}{ Zone of Inhibition (mm) } \\
\cline { 2 - 9 } & Leaves Methanol & \multicolumn{2}{|c|}{ Leaves water } & \multicolumn{2}{l|}{ Seeds methanol } & \multicolumn{2}{l|}{ Seeds water } \\
\hline & E.coli. & B.subtilis. & E.coli. & B.subtilis. & E.coli. & B.subtilis. & E.coli. & B.subtilis. \\
\hline 0.1 & 14 & 17 & 23 & 12 & 16 & 16 & 16 & 15 \\
\hline 0.2 & 30 & 22 & 15 & 14 & 36 & 19 & 17 & 17 \\
\hline 0.4 & 24 & 23 & 12 & 15 & 38 & 33 & 20 & 18 \\
\hline 0.6 & 26 & 27 & $-v e$ & 16 & 22 & 26 & 17 & 16 \\
\hline
\end{tabular}

In some cases, it was observed that the zone of inhibition decreases with the increase of extracts which indicates that the microbes/ pathogen have adapted a resistivity towards the extracts that were used. Hence small quantities of plant extracts also are effective to effective to control the growth of bacteria and fungus. Otherwise there was a chance that the organisms become resistant towards the extracts.

\section{Conclusion}

Natural plant compounds have also been shown to antimicrobial properties and may be an alternative to synthetic chemical agents. The present study concluded that the presence of multiactive secondary metabolites which was present in the leaf and seed extracts of the Clitoria ternatea have made the plant a very important medicinal plant. Seed methanol extract have high content of phenol whereas leaves methanol have high content of flavonoid. Carbohydrate content was almost equal in all the extract. Tannin was of low content in all the extract. Leaves aqueous extract contain terpenoid. The positive results of antimicrobial activity against the bacteria and the fungus also revealed the importance of this plant. In conclusion, all plant extracts of Clitoria ternatea possessed activity against at least one strain of bacteria and/or fungi. Further studies aimed at the isolation and identification of active substances from the methanol extracts of $\mathrm{C}$. ternatea could also disclose compounds with better value for food preservation as well as natural plant based medicine. It would become a base for the development of new drug which could be useful in treatment of diseases. 


\section{Acknowledgements}

The authors are very much thankful to Dr Shovan Kumar Mishra, Director of Tectona Biotech Resource Centre, Bhubaneswar, Odisha for providing the necessary facilities to carry out the research work. The authors are also grateful to research centre realizing the need of research, training and education for generating interdisciplinary human resource relevant to biotechnology for creating best skill development and research in biotechnology through co-operation and help from all sectors providing a place where innovation enterprise and Industrial development will generate as far as practicable.

\section{References}

[1] Darsini, I. P., Shamshad, A. S. 2013. Antimicrobial Activity and Phytochemical Evaluation of Clitoria ternatea. International Journal of Science and Research 4:823-825.

[2] Esmail, A., Snafi A. 2016. Pharmacological Importance of Clitoria ternatea - A review. Journal of Pharmacy 6:68-83.

[3] Gupta, G.K., Chahal J., Bhatia M. 2010. Clitoria ternatea (L.): Old and new aspects. Journal of Pharmacy Research 3:610-2614.

[4] Haripriya, D., Selvan, N., Jeyakumar, N., Periasamy, R., Johnson, M., Irudayaraj, V. 2010. The effect of extracts of Selaginella involvens and Selaginella inaequalifolia leaves on poultry pathogens. Asian Pac J Trop Med 3:723-726.

[5] Indumathi, C., Durgadevi, G., Nithyavani, S., Gayathri, P.K. 2014. Estimation of Terpenoid Content and Its Antimicrobial Property in Enicostemma litorrale International Journal of ChemTech Research 6:4264-4267.

[6] Kamtekar, S., Keer, V., Patil, V. 2014. Estimation of Phenolic Content, Flavonoid Content, Antioxidant and Alpha-amylase Inhibitory Activity of Marketed Polyherbal Formulation . Journal of Applied Pharmaceutical Science 4:061-065.

[7] Kavitha, L.R., and Premalakshmi, V. 2013. Phytochemical Analysis of Ethanolic Extract of Leaves of Clitoria ternatea. International Journal of Pharma and BioSciences 4:236-242.

[8] Lakshmia, D. M., Mahithaa, B., Madhavia, T., Sushma, J. 2015. N. Phytochemical Screening and Ftir Analysis of Clitoria ternatea Leaves. International Journal of Scientific \& Engineering Research 6:287-290.

[9] Barik, D.P., Naik, S.K., Mudgal, A. and Chand, P.K. 2007. Rapid Plant regeneration through in vitro auxiliary shoot proliferation of butterfly pea (Clitoria ternatea L.) a twining legume. In vitro cell. Dev. Biol. Plant 43:144-148.

[10] Yogendrasinh, B., Solanki., and Sunita. M. 2010. Immunomodulatory activity of ayurvedic plant aparajita in male albino rats. Glo. j. science frontier res. 10: 2-8.

[11] Pahune, B., Niranjane K., Danao, K., Bodhe, M., and Rokade, V. 2013. Antimicrobial Activity of Clitoria ternatea L. flower extract and use as a natural indicator in acid base titration. J. Nat. Prod. Plant Resour. 3:48-51.

[12] Salhan, M., Kumar, B., Tiwari, P., Sharma, P., Sandhar, H.K., and Gautam, M. 2011. Comparative Anthelmintic Activity of aqueous and ethanolic leaf extracts of Clitoria ternatea. International Journal of Drug Development and Research 3: 68-69.

[13] Okwu, D.E. and Josiah, C. 2006. Evaluation of the chemical composition of two Nigerian medicinal plants. Afri. J. Biotech 5:357-361.

[14] Gupta, G.K., Chahal, J., and Bhatia, M. 2010. Clitoria ternatea (L.) Old and new aspects. Journal of Pharmacy Research 3 (11) 2610-2614.

[15] Terahara, N., Saito, N., Matsui, T., Osmajima, Y., and Saito. N., 1996. Five New Anthocyanins A3, B4, B3, B2 and D2 from Clitoria ternatea. J Nat Prod 59: 139-144. 
[16] Uma, B. 2009. Phytochemical analysis and antimicrobial activity of Clitoria ternatea Linn. against extended spectrum beta lactamase producing enteric and Urinary Pathogens. Asian Journal of Pharmaceutical and Clinical Research 2:0974-2441.

[17] Manalisha, D., and Chandra, K.J. 2011. Preliminary phytochemical analysis and acute oral toxicity study of Clitoria ternatea Linn. in albino mice. International Research Journal of Pharmacy 2:139-140.

[18] Manjula, P., Sreekanth, M.C., Keerthi, B., Devi, B.P. 2013. Phytochemical Analysis of Clitoria ternatea linn., A valuable medicinal plant. Journal of Indian Botanical Society 92: 173-178.

[19] Haripriya, D., Selvan, N., Jeyakumar, N., Periasamy, R,, Johnson, M., and Irudayaraj, V. 2010. The effect of extracts of Selaginella involvens and Selaginella inaequalifolia leaves on poultry pathogens. Asian Pac. J Trop Med.

*Corresponding author.

E-mail address: souvagya.tbrc@ gmail.com 